\title{
Blended Web Mobile Learning (BWML) Model to Improve Students' Higher Order Thinking Skills
}

$\underline{\text { https://doi.org/10.3991/ijet.v15i11.12853 }}$

\author{
Binar Kurnia Prahani ${ }^{\left({ }^{\circ}\right)}$, Budi Jatmiko \\ Surabaya State University, Surabaya, Indonesia \\ binarprahani@unesa.ac.id \\ Bambang Hariadi, Dewiyani Sunarto, Tri Sagirani, Tan Amelia, \\ Julianto Lemantara \\ Dinamika University, Surabaya, Indonesia
}

\begin{abstract}
The results of literature review show that Problem Based Learning (PBL) and Hybrid Learning models have been proven to increase students' higher order thinking skills (HOTS), but also still have weaknesses that need to be refined. To complete the weaknesses in the implementation of the PBL Model and the Hybrid Learning Model, it is necessary to develop an Innovative Learning Model that can increase students' HOTS. The BWML (Blended Web Mobile Learning) Model is a learning model that integrates the Hybrid Learning model with PBL model, which is supported by the use of MoLearn application in each learning activity. The development of the Blended Web Mobile Learning model is supported by the latest learning theories and the empirical foundation of the latest research. The BWML model has five phases, namely: (1) Orientation based on IoTs and Big Data, (2) Investigation, (3) Analyzing, (4) Presenting, and (5) Evaluating, which each phase is carried out and supported by using the MoLearn application. The emphasis on BWML model implementation use percentage of $70 \%$ (on the job experience), $20 \%$ (mentoring and coaching), and 10\% (classroom, course, and reading).
\end{abstract}

Keywords-Higher order thinking skills, BWML, MoLearn

\section{$1 \quad$ Introduction}

The $21^{\text {st }}$ Century learning and in the era of industrial revolution 4.0 requires human resources with competency standards for graduate students who are directed at higher order thinking skills (HOTS) and innovative learning, including: critical thinking skills, problem solving skills, literacy, collaboration, decision making, think creatively, be responsible, and be able to learn independently [1-3]. Based on these competencies, education in Indonesia has a significant role in striving for the quality of the process and learning outcomes in accordance with the demands of the 2013 Curriculum and KKNI, including HOTS-based student learning processes and outcomes through effective and efficient learning. 
In connection with improving the quality of students' learning process and outcomes according to the demands of the 2013 Curriculum and KKNI in the era of the industrial revolution 4.0 above, there are important problems faced by the Indonesian education world today, namely how to strive the HOTS improvement [4-7]. One of them is on high-level thinking skills through innovative learning that integrates web and mobile learning into effective and efficient learning.

HOTS is a student learning achievement that involves the high hierarchy cognitive level thinking activities of Bloom's thinking taxonomy. Hierarchically from Bloom's taxonomy, HOTS indicators include analyzing, evaluating, and creating [8]. HOTS is very important because it provides students competency to compete and excel in the era of the industrial revolution 4.0. Therefore, the urgency of HOTS must really be strengthened through innovative learning models in Indonesia. Reinforced by research results $[4,6,7]$ which show that the learning process still use teacher center and more emphasis on the process of knowledge transfer so that it has not been able to make students capable in constructing knowledge. The low HOTS of students is thought to be related to the used learning process. The learning model used, namely the conventional learning model is less able to facilitate the development of students' HOTS-based learning outcomes, so it can be suspected as a cause of the low learning achievement [2-8]. Therefore, to improve the quality of students' learning outcomes in Indonesia in accordance with the demands of the 2013 Curriculum and KKNI in the era of the industrial revolution 4.0 and in order to facilitate the HOTS-based learning process and results of students through effective and efficient learning, alternative solutions need to be sought. As an alternative solution to these problems, among others, is by developing innovative learning models that can improve students' HOTS.

This paradigm shift in learning certainly has an impact on the demands of changing the educators' ability. Educators are not enough to just hone their abilities in material / scientific fields, but also on the methods and media that will be used, especially methods and media that use information technology. This is based on the fact that students today are students in the Generation $\mathrm{Z}$ era [9]. Adjusting to the characteristics of Generation $Z$, learning cannot be done conventionally. Educators cannot turn a blind eye to Generation Z's need for learning models that adapt to their characteristics. Learning is centered on educators, learning media are only face-to-face, paper assignments are collected, working on assignments must be at home or on campus, educators can only be met through face-to-face, it is not appropriate for current students anymore. Educators must begin to think of a learning model that can align themselves with the needs of students, who always follow the rapid development of the current gadget. However, this does not mean leaving the conventional method, namely face to face, because a touch of humanity is still needed. This concept is often referred to as Hybrid Learning.

The results of the literature review about PBL Model [10-31] and Hybrid Learning Model [32] have been proven to increase students' HOTS, but also still have weaknesses that need to be refined. To complement the weaknesses in the implementation of the PBL Model and the Hybrid Learning Model [28-32], it is necessary to develop an Innovative Learning Model that can increase students' HOTS. This is because the facts above have become a serious problem in the world of education in Indonesia. As an alternative solution that can be taken to answer the above problems by developing an 
innovative learning model that can increase students' HOTS to prepare them to excel in competing in the $21^{\text {st }}$ Century and the industrial revolution era 4.0, the developed innovative learning model is the Blended Web Mobile Learning (BWML) model that is feasible to improve students' HOTS.

\section{Literature Review}

\subsection{The learning model characteristics}

The learning model is a frame of mind that guides someone to design and implement learning to help students to gain information, ideas, skills, values, ways of thinking, and the meaning of their expressions [33-34]. According to Arends [35] at least four specific characteristics of the learning model that can be used to achieve the learning objectives are (1) the logical theoretical rationale of the design, (2) the learning objectives of the developed model, (3) the teaching behavior that is needed for the learning to be done, and (4) the needed learning environment to achieve the learning objectives.

\subsection{PBL model}

The PBL model is a problem-based teaching that describes views on education in which schools are seen as a mirror of the community and the class becomes a laboratory for the investigation of daily life problems [35-36]. The PBL model also has five syntaxes, namely directing students to the problems, organizing students to learn, helping independent and group investigations, developing and presenting artifacts and exhibits, then analyzing and evaluating problem solving processes [35]. The characteristics of the PBL Model are designed to help students improving their investigation and problem-solving skills, social behavior and skills according to adult roles, and independent learning skills $[10,35]$.

The PBL model starts with real life which is complex [20], unstructured, and involves interdisciplinary content [21], involved in collaborative teaching to manage an increasingly diverse student population $[15,18]$. PBL is an important practice that provides a suitable learning environment for students [12,17,19,23]. The PBL model also regulates student-centered learning environments that are not seen as empty vessels, but are able to bring their own frameworks and different learning [13,14,30].

PBL model can improve independent learning skills and provide a more realistic picture of higher academic challenges, more confidence, can improve problem solving skills, critical thinking skills, and increase communication and literacy skills [1-27]. However, the PBL Model is still weak in terms of the orientation component of the investigation, alternative solutions, having difficulty in formulating problems and developing hypotheses, lack of giving initiation and time management, lack of student discipline, and need more challenging authentic problems [28-31]. Therefore, PBL still needs improvement and refinement in increasing students' HOTS in facing the era of the industrial revolution 4.0 . 


\subsection{Hybrid learning model}

The Hybrid Learning Model is a learning to provide the learning model contents in a variety media (including, but not limited to traditional, web-based, computer-based and video) to follow the current learning needs [32,37]. The application of Hybrid Learning can improve students' HOTS learning outcomes, but still needs improvement by integrating applications that can prepare high school students to compete in the industrial revolution era 4.0 that is marked by the Internet of Things (IoTs) and Big Data. Therefore, there is still a need for improvement and refinement of the Hybrid Learning model in increasing the students' HOTS in welcoming the era of the industrial revolution 4.0.

\subsection{MoLearn application}

The MoLearn application is an application for Hybrid Learning that has been developed in Business and Informatics Institute of Stikom Surabaya (Dynamics University, Surabaya, Indonesia) with the aim of increasing students' HOTS. MoLearn application is free access for another people in the world. The mobile-based learning application is called as 'MoLearn' for both web version and android version. The produced learning applications 'MoLearn' can be grouped into two, namely (1) the web version and (2) the android version. This MoLearn application is a hybrid learning application, it can be used for face-to-face learning (with teachers) and for independent learning without teachers. In the 'MoLearn' web version and android version, the initial appearance when we enter will look like Figure 1.

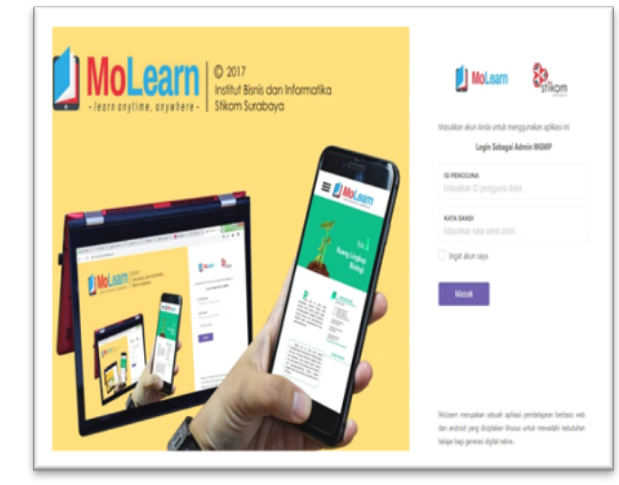

a) Web Version

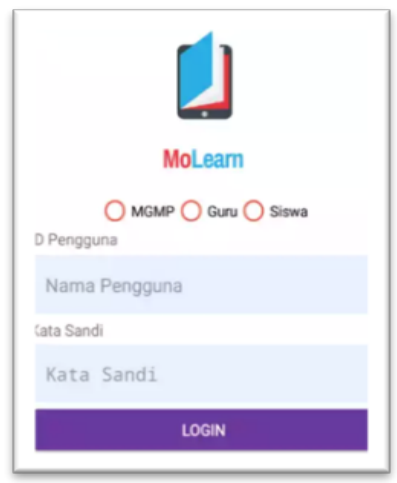

b) Android Version

Fig. 1. Initial Display of 'MoLearn'

(Source: https://www.molearn.net/) 
The MoLearn application provides learning tools that utilize the Internet of Things (IoTs). By using the concept of Hybrid Learning, learning is not only carried out in the classroom, but also carried out in cyberspace so that students can learn anywhere, anytime, with anyone, through any media. In the MoLearn application, the teacher functions as a facilitator, guide, and consultant so that students are required to learn actively. To produce a learning process that can help students, teachers act as facilitators and be able to make students active to learn in the classroom and cyberspace, the MoLearn application is the right learning application.

\section{Discussions}

\subsection{Characteristics of BWML model}

The BWML Model have 3 (three) major characteristics, they are: (1) The Logical Theoretical Rationale of Learning Model Design, (2) The Purpose of BWML model Development, (3) Learning Environment.

The logical theoretical rationale of learning model design: The development of the Blended Web Mobile learning model is supported by current learning theories (constructivism, learning through observation, discovery learning, cognitive processes, metacognition, and scaffolding), the empirical foundation of the latest research and scientific publications of researchers as presented in Figure 3. These theories form the basis in compiling the steps of the BWML Model, which has five phases, namely: (1) Orientation based on IoTs and Big Data, (2) Investigation, (3) Analyzing, (4) Presenting, and (5) Evaluating, which each phase is implemented and supported by using the MoLearn application. The emphasis on BWML implementation use a percentage of $70 \%$ (on the job experience), 20\% (mentoring and coaching), and 10\% (classroom, course, and reading) [32-33].

To optimize the impact of applying the BWML Model, which is to improve students' literacy skills and critical thinking skills, both instructional and accompanying impacts, the implementation of the model with regard to the teacher's way of managing learning will be describe, it includes: (1) planning tasks; (2) interactive tasks; (3) learning environment and task management; and (4) Evaluating. The things done on these planning tasks are: (1) formulating goals; (2) choosing content, (3) doing a task analysis; and (4) planning time and space.

The main idea that becomes the background of task analysis is that the completely complex understanding and skills cannot be learned in a given time. To develop easy understanding and ultimately improve data literacy skills and critical thinking skills must be divided into logically sequential parts and step-by-step. Interactive tasks based on IoTs and Big Data in the application of the BWML Model for learning outcomes to improve students' HOTS in welcoming the industrial revolution era 4.0 is referring to the phases in the syntax of the BWML Model as presented in Figure 3.

Teacher must identify the compatibility between the materials taught by the BWML Model to students. The discussion order of the material, whether it is done directly by the teacher or presented in the textbook must be arranged logically, so students can 
easily see the relationship between facts and key concepts that are the subject matter in various IoTs and Big Data-based. This model emphasizes investigation through hybrid learning based practice or experiments. Therefore, the selection of material must be related to phenomena in everyday life or to relate to a phenomenon based on IoTs and Big Data.

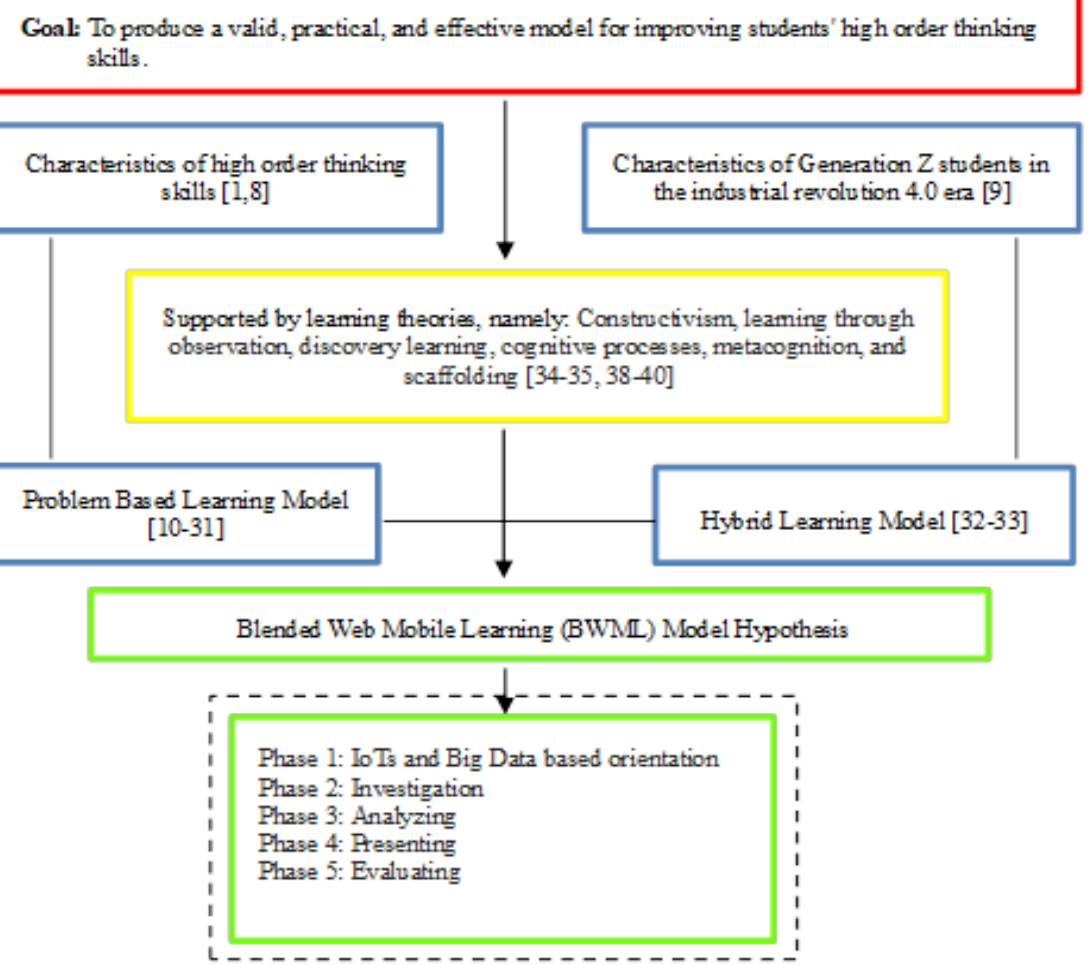

Fig. 2. Rationality of the Developed a BWML Model

Phase 1: IoTs and big data-based orientation: Aiming to attract students 'interests, focus students' attention, and motivate them to play an active role in the learning process. In this phase the MoLearn application plays an important role in the success of phases 2, 3, 4, and 5 because the teacher's ability to use the MoLearn application will facilitate the management of real and virtual classes where students will be more motivated and interactive in learning. In addition, students have been directed to understand IoTs and Big Data based problems that they must solve in the learning process. This phase is supported by cognitive theory, which explains that learning as a relatively persistent change in mental structure that occurs as a result of the individuals' interaction with the environment. Students share ideas with others to improve their understanding, because they are encouraged to clarify and organize their own ideas, elaborate what 
they know, find weaknesses in reasoning, and enjoy alternative views that are as valid as those they have that is known as distributed cognition learning [38].

Piaget explained that students are natural explorers who are always curious to continue trying to understand the world by interacting with their environment and others [38]. For example, when students experience learning disabilities (difficulty in obtaining and using reading, writing, reasoning, listening, or mathematics ability), they will think of finding new ways and stepping into new stages of development [39-40]. Cognitive strategies are the ways students have in managing the learning process. If a student is confronted with a new problem, then to solve it they must connect with the results of previous learning, namely information and intellectual skills that have been learned (phase 1: IoTs and Big Data based Orientation), and must have a strategy to solve the new problem.

Findings from cognitive psychology provide a theoretical foundation for the BWML Model. The basic premise in cognitive psychology is that learning is a process of constructing new knowledge based on current knowledge. Learning is a constructive process and not acceptance [42-43]. Cognitive processes called metacognition affect the use of knowledge, and social and contextual factors in learning. This theory underlies phase 1. Dewey's Pedagogy encourages teachers to involve students in problem-oriented projects and helps to investigate important social and intellectual problems. Dewey and his followers insisted that learning in schools should be more meaningful (purposeful), not too abstract [46-47]. The purposeful vision of learning in problem centered is supported by the innate desire of students to explore situations personally for them.

Phase 2: Investigation: This is aiming to gather information with the help of worksheets, then the teacher guides to carry out a step-by-step inquiry by using the MoLearn application, seeking explanations and solutions to build students' HOTS through scientific inquiry activities. This phase is supported by sociocognitive theory that is focusing on learning as a result of observing others or observing the consequences of other people's behavior. Students actively construct their knowledge from personal experiences with others and the environment [38]. Teachers can develop students' HOTS by providing learning environments, materials, tasks that stimulate and encourage them to construct their own data literacy abilities through observation and experimentation. The teacher uses an advanced organizer to help students encode new information [38,40]. The teacher helps to understand pedagogical knowledge (teaching strategies that is specific to the taught content) and pedagogic content knowledge (making a topic understood by students, and understanding what makes learning a particular topic easy or difficult) [38-39]. Strengthened by Bandura's Theory that explains social learning occurs from the results of observing the behavior of others and the environment. Such learning involves processing information in four stages, including: (a) attention, (b) retention, (c) production, (d) motivation [38]. Bandura also introduced self-regulated learning, a process of setting personal goals, combined with motivation, thought processes, strategies, and behaviors that lead to the achievement of goals [39].

Bruner emphasizes constructivism through discovery learning, namely processing what students know about new situations [38]. Students are accustomed to actively par- 
ticipating in constructing concepts and principles to gain experience and conduct experiments to discover the concepts and principles themselves [41]. Learning with problems by John Dewey describes the view of education, with the school as a mirror of the larger community and classrooms as a laboratory for the investigation and resolution of real-life problems.

Phase 3: Analyzing: The aim is to guide students in making analysis, conclusions and discussion of the investigations results. Improving students' HOTS will be developed in this phase because students are encouraged to analyze the data investigation results optimally to answer problems in phase 2. This phase is supported by Vygotsky theory that explain four learning principles: (a) social learning, students actively constructing their knowledge through personal experiences with others and the environment $[38,40]$; (b) the Zone of Proximal Development (ZPD), assistance is intended so that students are able to work on tasks or questions that are higher in complexity than cognitive development; (c) cognitive apprenticeship, the process of making students gradually gain intellectual skills through interactions with people who are more expert, adults, or smarter friends; and (d) The teacher uses scaffolding to help students overcoming certain problems that are beyond their developmental capacity with the help of more capable friends or teachers [35]. Assistance in the form of instructions, encouragement, warnings, breaking down problems into solving steps, providing examples, and other actions that enable students to be able to learn independently.

Strengthened by Bruner [48] who provides theoretical support for discovery learning, a teaching model that emphasizes the importance of helping students to understand the structure or key ideas of a discipline, the need for active student involvement in the learning process, and the belief that true learning takes place through personal discovery. When discovery learning is applied in the fields of science and social science, Bruner emphasizes inductive reasoning and the process of inquiry that characterizes the scientific method. Problem-based learning is also aware of another concept originating from Bruner, namely the idea of scaffolding. According to Bruner, scaffolding is a process of students who are helped to overcome certain problems that are beyond their developmental capacity with the help of teachers or people who are more capable.

Phase 4: Presenting: Aims to make conclusions and discussion of the investigation results in various representation, and help to guide students in planning, preparing, and presenting their work with hybrid learning based on IoTs and Big Data. Students' HOTS will be enhanced in this phase because students are encouraged to be optimal in analyzing the data investigation to answer problems in phase 3. This phase is supported by Vygotsky's theory that emphasizing constructivism through two main ideas, namely: (a) students' intellectual development can be understood only in the cultural and historical context of their experience; and (b) intellectual development depends on the sign system of each individual. Multi representation has three main functions, namely as a complementary, limiting interpretation, and understanding builders [49-50]. Sign systems are symbols that are created culturally to help someone in thinking, communicating, and solving problems, for example, language culture, writing systems, and calculation systems [40]. Students become easier to transfer what is learned to solve real life problems when contextual learning activities are presented (phase 4: Presenting). Students ultimately integrate reading, writing, and language and communication skills 
throughout the curriculum in authentic contexts or real-life materials, problems, and assignments that is known as whole language learning [40].

Phase 5 Evaluating: Aiming to carry out evaluation processes, problem solving, and processes based on IoTs and Big Data, see students' work as evidence of learning, and facilitate follow-up learning through structured assignments in each phase, which are needed by using the MoLearn application. This phase is supported by the results of required research by students on how to learn and take steps to obtain maximum learning outcomes. Students are required to do learning (learning through the process of assessing from their own learning) and reflection (the process of thinking about think and practice by HOTS, learning from the process, and applying what is learned to improve future actions) $[38,40]$.

Strengthened by intrinsic theory, which states that students provide feedback to help improving the working quality, self-perception, and intrinsic motivation [39]. Students who are intrinsically motivated on certain activities or topics will focus their efforts on learning and produce higher performance with only a little effort $[38,40]$. Lev Vygotsky also believes that intelligence is developed when individuals face new experiences and try to overcome arisen problems. Efforts in overcoming problems are done by connecting new knowledge with prior knowledge and constructing new knowledge. Vygotsky stressed the importance of the social aspects of learning because social interaction with others spurs the construction of new ideas and enhances students' intellectual development [44-45]. The results of research on the use of ICT in learning can improve student learning outcomes [51-55].

The purpose of BWML model development: Each learning model has specific characteristics to teach certain learning outcomes, as well as the learning model that will be developed. Learning models that are already available are not maximized to increase students' HOTS and prepare students to excel in competing in the $21^{\text {st }}$ century and the era of the industrial revolution 4.0, so the development of this model is designed to fill these gaps.

Learning environment: As in general learning models, teaching and learning activities use the BWML Model to improve students' HOTS, teachers plan activities in a structured and rigorous manner through the MoLearn application. The successful use of this learning model is determined by the preparation of a good learning environment and learning media [51] to support every teacher and student activity at every stage in the syntax of the BWML Model by using the MoLearn application to improve students' HOTS

\subsection{Component of BWML model}

The learning process in the developed learning model is contained in the components of the BWML model. According to Joyce et al [5], a good learning model should have 5 (five) major components in the model, they are: (1) Syntax, (2) Social systems, (3) Reaction principles, (4) Support systems, (5) The instructional and companion impact.

Syntax: The BWML model has five-phase syntax; they are: (1) Orientation based on IoTs and Big Data; (2) Investigation; (3): Analyzing; (4): Presenting; and (5) evaluating. 
Table 1. Syntax of BWML model

\begin{tabular}{|l|l|l|}
\hline \multicolumn{1}{|c|}{ Learning Activity } & \multicolumn{1}{|c|}{ HOTS Indicator } & \multicolumn{1}{|c|}{ Allocation Distribution } \\
\hline $\begin{array}{l}\text { Orientation based on IoTs } \\
\text { and Big Data }\end{array}$ & Analyzing (C4) dan Evaluating (C5) & \multicolumn{1}{|c|}{$10 \%$ (classroom, course, and reading) } \\
\cline { 1 - 2 } Investigation & $\begin{array}{l}\text { Analyzing (C4), Evaluating (C5), and } \\
\text { Creating (C6) }\end{array}$ & $70 \%$ (on the job experience) \\
\cline { 1 - 2 } Analyzing & $\begin{array}{l}\text { Analyzing (C4), Evaluating (C5), and } \\
\text { Creating (C6) }\end{array}$ & \\
\hline Presenting & $\begin{array}{l}\text { Analyzing (C4), Evaluating (C5), and } \\
\text { Creating (C6) }\end{array}$ & \\
\hline Evaluating & Evaluating (C5) & $20 \%$ (mentoring and coaching) \\
\hline
\end{tabular}

Table 2 shows that the core of the Blended Web Mobile learning model implementation has a percentage of $70 \%$ (on the job experience), $20 \%$ (mentoring and coaching), and $10 \%$ (classroom, course, and reading) to maximize the increase of students' HOTS in welcoming the industrial revolution era 4.0.

Social system: The social system in the learning model is based on constructivist Vygotsky. The social system that exists in the syntax of the model include the relationship of students with other students and the relationship of students with teachers. This social system emphasizes the construction of knowledge that every student actively engages, but the construction will be stronger if it is done collaboratively. Based on the syntax that has been prepared, the recommended social system is: (1) Students are proactive in learning activities by contributing to students' HOTS in groups; (2) The teacher acts as a guide, moderator, facilitator, consultant and mediator in the learning process to improve students' HOTS.

Reaction principles: This reaction principle is related to how students pay attention and treat other students, including students respond to questions, answers, responses, or what other students do. In the WBML Model by using the MoLearn application, the way teachers' pay attention and treat students should be: (1) Teachers motivate and remind students to always emphasize students' HOTS; (2) The teacher provides feedback, praise, an opportunity for students to ask questions, think, criticize the learning process so that the students' HOTS increases; (3) Emphasis on BWML implementation with a percentage of $70 \%$ (on the job experience), $20 \%$ (mentoring and coaching), and $10 \%$ (classroom, course, and reading).

Support systems: The support system of a learning model is all the instruments, materials and tools for implementing the WBML Model by using the MoLearn application. The support system in the WBML Model by using the MoLearn application are: (1) Learning instruments of the WBML Model are: Syllabus, lesson plan, worksheet, Student Teaching Materials, and HOTS evaluation instruments; (2) MoLearn application as the main support in learning; and (3) Learning media in the form of virtual labs and provided by computers or laptops, as well as internet networks in accessing data literacy.

Instructional impact and nurture impact: One reference of the learning model is said to be effective if the application is able to produce and achieve what the main goal as an instructional impact of the learning. The instructional impact of the WBML Model by using the MoLearn application is that students are able to increase their HOTS. The 
accompanying impact is another learning outcome created from the learning process experienced by students with the teacher's direction. The nurture impact of the WBML Model by using the MoLearn application are: (1) The concepts mastery, (2) ICT Literacy, (3) Student activities towards positive learning, (4) Student responses to positive learning.

\subsection{The benefits of BWML model development}

The developed learning models through theoretical and empirical studies are expected to provide several benefits including: (1) Alternative choices of learning models that can be used to train students to improve HOTS; (2) The availability of learning models that can bridge the students' HOTS that is needed in the $21^{\text {st }}$ century; and (3) reference material in developing other learning models.

\section{Conclusion}

The BWML Model is a learning model that integrates the Hybrid Learning Model with the PBL Model, which is supported by the use of the MoLearn application in each learning activity. The development of the BWML Model is supported by current learning theories (constructivism, learning through observation, discovery learning, cognitive processes, metacognition, and scaffolding), empirical foundations of current research and scientific publications of researchers. The BWML model has five phases, namely: (1) Orientation based on IoTs and Big Data, (2) Investigation, (3) Analyzing, (4) Presenting, and (5) Evaluating, which in each phase is carried out and supported by using the MoLearn application. Emphasis on BWML implementation with a percentage of $70 \%$ (on the job experience), $20 \%$ (mentoring and coaching), and 10\% (classroom, course, and reading). Further research is necessary to prove that the hypothetical BWML model is feasible by fulfilling the validity, practicality, and effectiveness to improve HOTS of students.

\section{$5 \quad$ References}

[1] Griffin, P. \& Care, E. (2015). Assesment and teaching of 21st century skills: Methods and approach. New York: Springer.

[2] Klegeris, A., Bahniwal, M., \& Hurren, H. (2013). Improvement in generic problem-solving abilities of students by use of tutor-less problem-based learning in a Large Classroom Setting. CBE-Life Science Education, 12, 73-79. https://doi.org/10.1187/cbe.12-06-0081

[3] Wicaksono, I., Wasis, and Madlazim. (2017). The effectiveness of virtual science teaching model (VS-TM) to improve student's scientific creativity and concept mastery on senior high school physics subject. Journal of Baltic Science Education, 16(4), 549-561.

[4] Ennis, R.H. (2011). Critical thinking: Reflection and perspective-Part I. Inquiry, 26(1), 418. 
[5] Prayogi, S., Yuanita, L., \& Wasis. (2018). Critical inquiry-based learning: A model of learning to promote critical thinking among prospective teachers of physics. Journal of Turkish Science Education, 15(1), 43-56. https://doi.org/10.1088/1742-6596/947/1/012013

[6] Siswanto, J., Susantini, E., \& Jatmiko, B. (2018). Practicality and effectiveness of the IBMR teaching model to improve physics problem solving skills. Journal of Baltic Science Education, 17(3), 381-394.

[7] Temel, S. (2014). The effects of problems-based learning on pre service teachers' critical thinking dispotitions and perceptions of problems solving ability. South African Journal of Education, 34(1), 1-20.

[8] Anderson and Krathwohl. (2001). A taxonomy for learning, teaching and assessing: Revision of bloom's taxonomy of educational objectives. New York: Longman.

[9] Nichols, J. R. (2015). 4 Essential Rules Of 21st Century Learning. Teach Thought.

[10] Arizaga, M. P. G., Bahar, A. K., Maker, C., Zimmerman, R., \& Pease, R. (2016). How does science learning occur in the classroom? students' perceptions of science instruction during the implementation of REAPS Model. Eurasia Journal of Mathematics, Science \& Technology Education, 12(3), 431-455. https://doi.org/10.12973/eurasia.2016.1209a

[11] Benade, L. (2017). Being a teacher in the 21 st century: A critical new zealand research study. New York: Springer.

[12] Caesar, M. I. M., Jawawi, R., Matzin, R., Shahrill, M., Jaidin, J. H., \& Mundia, L. (2016). The benefits of adopting a problem-based learning approach on students' learning developments in secondary geography lessons. International Education Studies, 9(2), 51-65. https://doi.org/10.5539/ies.v9n2p51

[13] Chakravarthi, S. (2010). Implementation of PBL curriculum involving multiple disciplines in undergraduate medical education programme. International Education Studies, 3(1), 165 169. https://doi.org/10.5539/ies.v3n1p165

[14] Efendioglu, A. (2015). Problem-based learning environment in basic komputer course: preservice teachers' achievement and key factors for learning. Journal of International Education Research, 3(1), 205-216. https://doi.org/10.19030/jier.v11i3.9372

[15] Guilherme, E., Faria, C., \& Boaventura, D. (2016). Exploring marine ecosystems with elementary school Portuguese children: inquiry. https://doi.org/10.1080/03004279.2015. $\underline{1007884}$

[16] Leong, P. N. L. (2017). Promoting Problem-based Learning through Collaborative Writing. The English Teacher, XXXVII, 49-60.

[17] Myers, C. (2017). Law professors' existential online lifeworlds: A hermeneutic phenomenological study. Kansas State University.

[18] Kang, K.A., Kim, S., Kim, S.J., Oh, J., \& Lee, M. (2015). Comparison of knowledge, confidence in skill performance (CSP) and satisfaction in problem-based learning (PBL) and simulation with PBL educational modalities in caring for children with bronchiolitis. Nurse Education Today, 35(2), 315-321. https://doi.org/10.1016/j.nedt.2014.10.006

[19] Kong, L. N., Qin, B., Zhou, Y. Q., Mou, S.Y., \& Gao, H. M. (2014). The effectiveness of problem-based learning on development of nursing students' critical thinking: A systematic review and meta-analysis. International Journal of Nursing Studies, 51(3), 458-469. https://doi.org/10.1016/j.ijnurstu.2013.06.009

[20] Ledesma, D. (2016). Latinos in Linked Learning and California Partnership Academies: Sources of self-efficacy and social capital. California State University, Fresno.

[21] Loucky, J. P. (2017). Motivating and Empowering Students' Language Learning in Flipped Integrated English Classes. Flipped Instruction: Breakthroughs in Research and Practice: Breakthroughs in Research and Practice, 189-213. https://doi.org/10.4018/978-1-5225$\underline{1803-7 . \operatorname{ch} 012}$ 
[22] Malan, S. B., Ndlovu, M., \& Engelbrecht, P. (2014). Introducing problem-based learning (PBL) into a foundation programme to develop self-directed learning skills. South African Journal of Education, 34(1), 1-16. https://doi.org/10.15700/201412120928

[23] Nuninger, W. \& Châtelet, J.M. (2017). Pedagogical mini-games integrated into hybrid course to improve understanding of komputer programming: Skill building without the coding constraints gamification-based e-learning strategies for komputer programming education (152-194): IGI Global. https://doi.org/10.4018/978-1-5225-1034-5.ch008

[24] Şendağ, S. \& Odabaşı, H. F. (2009). Effects of an online problem-based learning course on content knowledge acquisition and critical thinking skills. Komputers \& Education, 53(1), 132-141. https://doi.org/10.1016/j.compedu.2009.01.008

[25] Tracey, D. H. \& Morrow, L. M. (2017). Lenses on reading: An introduction to theories and models. New York: Guilford Press.

[26] Williams, B. (2005). Case based learning-a review of the literature: is there scope for this educational paradigm in prehospital education? Emergency Medicine Journal, 22(8), 577581. https://doi.org/10.1136/emj.2004.022707

[27] Zabit, M. N. M. (2010). Problem-based learning on students' critical thinking skills in teaching business education in Malaysia: A literature review. American Journal of Business Education, 3(6), 19. https://doi.org/10.19030/ajbe.v3i6.436

[28] Ates, O. \& Eryilmaz, A. (2010). Factors affecting performance of tutors during problembased learning implementations. Procedia-Social and Behavioral Sciences, 2(2), 2325-2329. https://doi.org/10.1016/j.sbspro.2010.03.330

[29] Mataka, L.M., \& Kowalske, M.G. (2015). The influence of PBL on students' self-efficacy beliefs in chemistry. Chem. Educ. Res. Pract., 16, 929-938. https://doi.org/10.1039/c5rp $\underline{00099 h}$

[30] Sern, L. C., Salleh, K. M., Mohamad, M. M., \& Yunos, J. M. (2015). Comparison of example-based learning and problem-based learning in engineering domain. Universal Journal of Educational Research, 3(1), 39-45. https://doi.org/10.13189/ujer.2015.030106

[31] Thompson, G. L. P., McInerney, P., Manning, D. M., Mapukata-Sondzaba, N., Chipamaunga, S., \& Maswanganyi, T. (2012). Reflections of students graduating from a transforming medical curriculum in South Africa: a qualitative study. BMC Medical Education, 12(1), 49. https://doi.org/10.1186/1472-6920-12-49

[32] Watson, J. (2008). Blended learning: The converegence of online and face-to-face education. Florida: NACOL.

[33] Woolf, B. P. (2010). Building intelligent interactive tutors: Student-centered strategies for revolutionizing e-learning. MA: Morgan Kaufmann.

[34] Joyce, B., Weil, M., \& Calhoun, E. (2009). Models of teaching. New York: Pearson Education Inc.

[35] Arends, R. (2012). Learning to teach. New York: McGraw-Hill.

[36] Batdi, V. (2014). The effects of problem-based learning approach on students' attitude levels: A meta-analysis. Educational Research and Reviews, 9 (9), 272-276.

[37] Tim Brilian. (2015). Overview hybrid learning. Surabaya: STMIK Stikom Surabaya.

[38] Moreno, R. (2010). Educational psychology. New York: Jhon Wiley \& Sonc, Inc.

[39] Eggen, P. D. \& Kauchak, D. P. (2013). Educational psychology: Windows on clasrooms $\left(9^{\text {th }}\right.$ edition). New Jersey: Pearson.

[40] Slavin, E. R. (2011). Educational psychology: Theory and practice. Boston: Pearson.

[41] Gardner, H. (2011). Frames of mind: The theory of multiple intelligences. New York: Basic books.

[42] Jonassen, D. H. (2000). Toward a design theory of problem solving. Educational Technology Research and Development, 48(4), 63-85. https://doi.org/10.1007/bf02300500 
[43] Charmaz, K. (2011). Grounded theory methods in social justice research. The sage handbook of qualitative research, 4, 359-381.

[44] Chi, M. T., Glaser, R., \& Farr, M. J. (2014). The nature of expertise. New York: Psychology Press.

[45] Stiglitz, J. E., \& Greenwald, B. C. (2014). Creating a learning society: A new approach to growth, development, and social progress: Columbia University Press.

[46] Loughran, J. (2013). Developing a pedagogy of teacher education: Understanding teaching \& learning about teaching. New York: Routledge. https://doi.org/10.4324/9780203019672

[47] Helterbran, V. R. (2010). Teacher leadership: Overcoming' I am just a teacher' syndrome. Education, 131(2), 363.

[48] Bruner, W. M. (1979). Crack growth and the thermoelastic behavior of rocks. Journal of Geophysical Research: Solid Earth, 84(B10), 5578-559. https://doi.org/10.1029/jb084ib $10 \mathrm{p} 05578$

[49] Ainsworth, S. (1999). The functions of multiple representations. Computers \& Education, 33(2), 131-152.

[50] Ainsworth, S. (2006). "DeFT: A conceptual framework for considering learning with multiple representations". Learning and instruction. 16(3), 183-198. https://doi.org/10.1016/j. learninstruc.2006.03.001

[51] Johnson, W. L., Rickel, J. W., \& Lester, J. C. (2000). Animated pedagogical agents: Faceto-face interaction in interactive learning environments. International Journal of Artificial Intelligence in Education, 11(1), 47-78.

[52] Gong, Y. (2018). Innovative English Classroom Teaching Based on Online Computer Technology in Rural Middle and Primary Schools. International Journal of Emerging Technologies in Learning, 13(10), 4-14. https://doi.org/10.3991/ijet.v13i10.9449

[53] Hariadi, B., Sunarto, M.J.D., Sudarmaningtyas, P., \& Jatmiko. (2019). Hybrid Learning by Using Brilian Applications as One of the Learning Alternatives to Improve Learning Outcomes in College. International Journal of Emerging Technologies Learning, 14(10), 34-45. https://doi.org/10.3991/ijet.v14i10.10150

[54] The, M. M., \& Usagawa, T. (2018). Effectiveness of E-learning Experience through Online. International Journal of Emerging Technologies in Learning, 13(12) 157-176.

[55] Zhang, J. (2018). Blended Learning Innovation Model among College. International Journal of Emerging Technologies Learning, 13(10), 158-170.

\section{$6 \quad$ Authors}

Dr. Binar Kurnia Prahani \& Prof. Budi Jatmiko work in Surabaya State University, Surabaya, Indonesia.

Dr. Bambang Hariadi, Dr. Dewiyani Sunarto, Tri Sagirani, M.Sc., Tan Amelia, M.Sc., Julianto Lemantara, M.Sc. work in Dinamika University, Surabaya, Indonesia.

Article submitted 2019-12-20. Resubmitted 2020-02-07. Final acceptance 2020-02-26. Final version published as submitted by the authors. 